\title{
A novel germline mutation of $h M L H 1$ in a Korean hereditary non-polyposis colorectal cancer family
}

\author{
KI-HWAN KIM ${ }^{1 *}$, JU-YOUNG KIM ${ }^{2 *}$, SE-IG OH ${ }^{5}$, HAING-WOON BAIK ${ }^{2}$, DONG-WOOK KANG ${ }^{3}$, \\ SUNG-HEE JUNG ${ }^{4}$, JEONG-HOON RHO ${ }^{1}$ and IN-TAEK HWANG ${ }^{1}$ \\ Departments of ${ }^{1}$ Obstetrics and Gynecology, ${ }^{2}$ Biochemistry and Molecular Biology, ${ }^{3}$ Pathology and \\ ${ }^{4}$ Internal Medicine, Eulji University School of Medicine; ${ }^{5}$ Seoul Women's Hospital, Daejeon, Korea
}

Received December 24, 2008; Accepted February 18, 2009

DOI: 10.3892/ijo_00000258

\begin{abstract}
Hereditary non-polyposis colorectal cancer (HNPCC) is an inherited disease caused by a germline mutation of the mismatch repair (MMR) genes, and the distinctive feature is that colorectal and extracolonic malignancies occur early in life. We report on the case of a Korean HNPCC family with endometrial cancer, with the goal of elucidating the involvement of an MMR deficiency. Although the family history did not fulfill the Amsterdam criteria II, blood samples were subjected to genetic testing by the revised Bethesda guidelines. Immunohistochemistry and direct sequencing of the genomic DNA identified a $\mathrm{C}$ insertion at the 1780th base in exon 16 of $h M L H 1$, a pathogenic mutation that has not been reported before. By this mutation, premature termination at codon 592 resulted with an estimated deletion of $21 \%$ of the C-terminus of the hMLH1 protein. For early detection of the disease, the family was examined by colonoscopy and a gynecologic examination. The expression of $h M L H 1$ in colon tissues was analyzed by Western blot analysis. We observed that the C-terminus portion of the hMLH1 protein was truncated in the HNPCC family members. Two young family members with no clinical symptoms were newly diagnosed with colorectal cancer by colonoscopy and a pathological examination. Hereby, we identified a novel pathogenic germline mutation of $h M L H 1$ in a Korean HNPCC family. The loss of C-terminus of hMLH1 protein was thus considered to possibly play a role in the development of HNPCC with other tumors. Our findings might be useful for early diagnosis and management of the HNPCC family.
\end{abstract}

Correspondence to: Dr In-Taek Hwang, Department of Obstetrics and Gynecology, Eulji University School of Medicine, Daejeon 301-832, Korea

E-mail: ithwang@eulji.ac.kr

${ }^{*}$ Contributed equally

Key words: hereditary non-polyposis colorectal cancer, mismatch repair, $h M L H 1$

\section{Introduction}

Hereditary non-polyposis colorectal cancer (HNPCC) is an autosomal dominant syndrome, characterized by a predisposition to develop a number of cancers including colon and endometrial, urinary, extracolonic gastrointestinal, brain, and ovarian cancer (1). Other characteristics of the disease include an early age of onset and development of multiple synchronous or metasynchronous cancers in some patients (2). Earlier research performed worldwide on HNPCC and its frequency in patients with colorectal carcinoma suggested that it accounts for $5 \%$ of all colon cancers (3). The genetic basis of HNPCC is related to germline mutations in DNA mismatch repair (MMR) genes. The function of the MMR system is to replace and eliminate the single base mismatches and insertion-deletion loops. The functional inactivation of cellular DNA MMR leads to a microsatellite instability (MSI) phenotype resulting in mutations of repeated sequences in various tumor-related genes.

Disease-causing germline mutations in four MMR genes [MSH2 $(4,5), \operatorname{MLH1}(6,7), \operatorname{MSH6}(8,9)$ and PMS2 (10)] were described to date. Most HNPCC cases in which the genetic mutation has been identified are attributable to a mutation in one of two genes, MSH2 and MLH1. A review of the HNPCC mutation database revealed 448 different mutations, that primarily involve $\mathrm{MLH1}(50 \%), \mathrm{MSH} 2(39 \%)$ and $M S H 6$ (7\%), occurred in 748 families from all over the world (11).

Early detection of a germline alteration predicts HNPCC, allowing for preventative or early treatment for all family members. Predicting families with a high likelihood of having a disease causing mutation is of great importance, because mutation detection in a number of genes is time-consuming and costly. Therefore, efforts have been made to find the most sensitive clinical criteria, based on family history, to be used to select families for mutation detection analysis. Studies of families fulfilling the Amsterdam criteria, which are the most restrictive criteria for HNPCC, have identified germline $\mathrm{MSH} 2$ and $\mathrm{MLH1}$ mutations with a relatively high sensitivity (approximately 60\%) and specificity (approximately $70 \%)(12,13)$. Analysis of HNPCC cases identified by less strict criteria such as the Modified Amsterdam II and Bethesda criteria, which included extracolonic tumors, led to an increased sensitivity and a decreased specificity for the identification of germline $M S H 2$ and $M L H 1$ mutations. Early-onset colorectal 
cancer or cases with a family history of endometrial cancer have also been shown to be independent predictors of germline mutations $(14,15)$. These studies indicate that the restrictive criteria identify HNPCC cases with the highest likelihood of having a germline mutation but exclude many cases that have a germline mutation. In contrast, the less restrictive criteria identify almost all cases with a germline mutation but include many cases without a germline mutation. In a clinical setting where genetic testing is desirable but expensive, the established clinical criteria for HNPCC have significant disadvantages as a starting point for identifying individuals for testing.

In the present study, we report on a novel $h M L H 1$ gene mutation identified in a Korean family affected with HNPCC. The goal of this study is to provide the opportunity of early diagnosis, and management and to decrease the mortality of the HNPCC family by carrying out genetic and clinical analysis of the family.

\section{Patients and methods}

Patients. The clinical diagnosis of classical HNPCC was established and verified at Eulji University Hospital. Among the patients from the same hospital, three sisters simultaneously were diagnosed with endometrial cancer. After 6 years, two of the sisters also were diagnosed with colorectal cancer (Fig. 1). The women were recommended consultation regarding hereditary cancer due to their early development of cancer which occurred before age 50. This study was performed after explanation of the study's detail to each member of the family and informed consent was obtained from all analyzed subjects. The study has been approved by Eulji University's Institutional Review Board.

Immunohistochemistry. The colon cancer tissues were fixed in buffered formalin and embedded in paraffin. Five-micrometer sections were deparaffinized in xylene and rehydrated in graded alcohols followed by water. Slides were then rinsed with double distilled $\mathrm{H}_{2} \mathrm{O}$ and incubated in $0.3 \% \mathrm{H}_{2} \mathrm{O}_{2}$ for $30 \mathrm{~min}$ to block endogenous peroxidase activity. Antigen retrieval was accomplished by heating the sections in a pressure cooker at $120^{\circ} \mathrm{C}$ for $20 \mathrm{~min}$ in $0.01 \mathrm{M}$ citrate-buffered solution (pH 6.0). After being blocked with $1.5 \%$ normal mouse serum for $20 \mathrm{~min}$, incubations with primary monoclonal antibodies were performed with anti-hMLH1 (1:50) (Zymed, San Francisco, CA, USA) and anti-hMSH2 (1:50; Zymed) for $1 \mathrm{~h}$ at room temperature. After washing with $0.05 \mathrm{M}$ Tris-buffer (pH 7.6), biotinylated sheep anti-mouse secondary antibody (1:100, Dako, Glostrup, Denmark) was applied for $30 \mathrm{~min}$ at room temperature. After being washed three times with $0.05 \mathrm{M}$ Tris-buffer ( $\mathrm{pH} 7.6)$, sections were then incubated with streptavidin/biotinylated horseradish peroxidase (HRP). Development was done using 3,3'-diaminobezidine (Dako). Sections were then counterstained with hematoxylin and mounted routinely. The slides were evaluated under light microscopy (OlympusBX51; Olympus Corp., Tokyo, Japan) at magnification $\mathrm{x} 400$. The absence of nuclear staining in tumor cells was considered to be an abnormal pattern.

Molecular analysis of germline mutation. Genomic DNA was isolated from peripheral blood leukocytes from the family members using G-DEX ${ }^{\mathrm{TM}}$ genomic DNA extraction kit (iNtRON Biotechnology, Seoul, Korea), according to the manufacturer's instructions. The entire $h M L H 1$ and $h M S H 2$ coding region and splice junctions were amplified by polymerase chain reaction (PCR) from genomic DNA. The PCR primers were designed to include all exons, promoter and flanking intron region. Amplifications were performed in $12.5 \mu 1$ reaction mixtures containing PCR buffer $(10 \mathrm{mM}$ Tris- $\mathrm{HCl}, \mathrm{pH} 8.3,50 \mathrm{mM} \mathrm{KCl}, 1.5 \mathrm{mM} \mathrm{MgCl}{ }_{2}$ ), $0.2 \mathrm{mM}$ dNTPs, $0.4 \mu \mathrm{M}$ of each primer, $0.5 \mathrm{U}$ of Taq DNA polymerase (Solgent, Daejeon, Korea) and 200 ng genomic DNA. Following initial denaturation (at $94^{\circ} \mathrm{C}$ for $10 \mathrm{~min}$ ), 35 cycles (at $94^{\circ} \mathrm{C}$ for $30 \mathrm{sec}$, at $60^{\circ} \mathrm{C}$ for $45 \mathrm{sec}$, and at $72^{\circ} \mathrm{C}$ for $45 \mathrm{sec}$ ) and final extension (at $72^{\circ} \mathrm{C}$ for $10 \mathrm{~min}$ ) was performed. PCR products were purified with a QIA quick column PCR purification kit (Qiagen, Germantown, MD, USA) and directly sequenced in forward and reverse directions with ABI 3700 automated DNA sequencer (Applied Biosystems, Foster City, CA, USA). Each sequence was compared with the corresponding normal sequence.

Clinical analysis. After genetic counseling, a gynecologic examination (Papanicolaou smear and transvaginal ultrasound: TVUs) for non-pregnant women and a colonoscopy were performed on family members who had not yet taken routine examinations. The biopsy was performed for pathologic diagnosis of the abnormal colonoscopic findings, and normal colon tissue was obtained to confirm the difference in the expression of hMLH1 protein in the actual colon tissue. Endometrial sampling was also indicated when the endometrial thickness was $>12 \mathrm{~mm}$ in premenopausal women during the second week of the menstruation cycle.

Western blot analysis. We extracted proteins from normal colon tissue during colonoscopy. Colon tissue was homogenized in Proprep-protein extraction solution (iNtRON Biotechnology) containing $10 \mathrm{mM}$ sodium phosphate $(\mathrm{pH}$ 7.0), $1 \%$ Triton $\mathrm{X}-100,0.1 \%$ SDS, $2 \mathrm{mM}$ EDTA, $150 \mathrm{mM}$ $\mathrm{NaCl}, 50 \mathrm{mM} \mathrm{NaF}, 0.1 \mathrm{mM}$ sodium vanadate, $4 \mu \mathrm{g} / \mathrm{ml}$ leupeptin, $1 \mathrm{mM}$ PMSF, and protein concentration of the lysates were measured with a Bio-Rad protein assay kit (BioRad, Hercules, CA, USA). Equal amounts of proteins $(20 \mu \mathrm{g})$ were separated on a 4-20\% SDS-PAGE and transferred by electroblotting to a nitrocellulose membrane. Western blots were probed with the following primary antibodies: anti-MLH1 (C-20; Santa Cruz Biotechnology, Santa Cruz, CA, USA); anti-MLH1 (N-20; Santa Cruz Biotechnology); anti-ß-actin (for internal control; Sigma). The membranes were washed with blocking solution (PBST containing 5\% non-fat dry milk) at room temperature for $1 \mathrm{~h}$ and incubated for $2 \mathrm{~h}$ with the primary antibodies [1:500 for anti-MLH1 (C-20), (N-20) and $1: 5000$ for anti- $\beta$-actin] under the same conditions. The membranes were washed in PBST, and incubated for $1 \mathrm{~h}$ with HRP-conjugated sheep anti-mouse and donkey anti-rabbit immunoglobulin antibody (1:500) under the same conditions. After washing with PBST, the specific signals were detected with an enhanced chemiluminescence detection system (Amersham Pharmacia Biotech, Arlington Heights, IL, USA). 


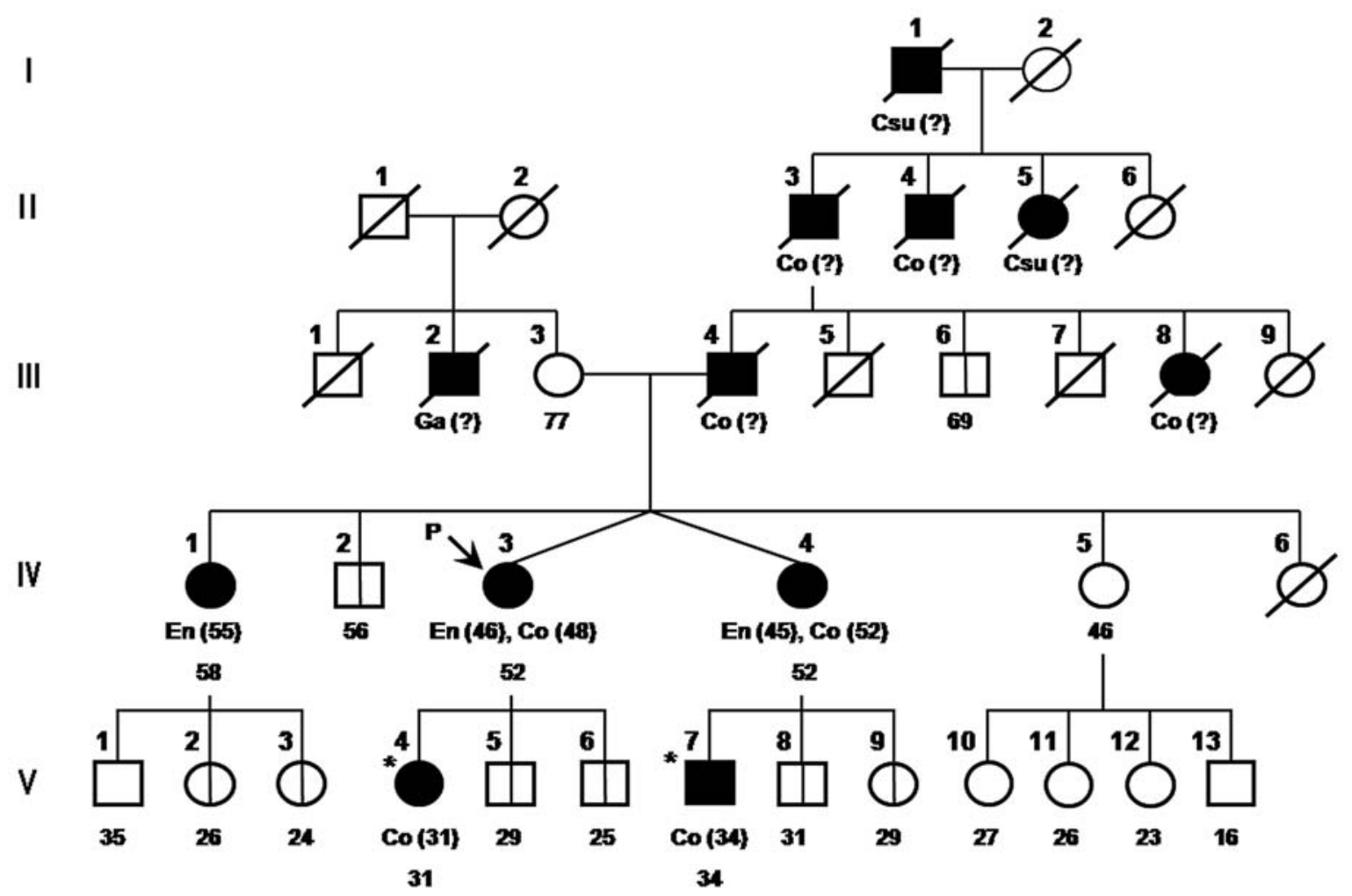

Figure 1. Pedigree of the HNPCC family. Squares, male; circles, female; open symbols, no tumor; solid symbols, patients with carcinomas; symbols with a diagonal line, deceased; symbols with centerline, non-penetrant carrier. Letters indicate the site of cancer. Co, colorectal cancer; En, endometrial; Ga, gastric; Csu, cancer site unknown. Numbers in parenthesis indicate the age of diagnosis as affected or unaffected. Numbers under the symbols indicate the current age. Numbers above the symbols indicate the individual number. Star indicates newly found carcinoma by clinical analysis. Arrow indicates the proband.

\section{Results}

Pedigree of the family. As shown in the Fig. 1, endometrial adenocarcinoma and/or colon adenocarcinoma occurred in three sisters (IV1, IV3, IV4), and two of them were diagnosed before 50 years of age. Also, there were members who died of colon cancer in the preceding three generations according to family history, which makes paternal inheritance of HNPCC strongly suspicious. However, they did not fulfill the Amsterdam Criteria II $(16,17)$ because the diseases outside generation IV were not confirmed pathologically. They needed a test for a mismatch repair gene based upon the Revised Bethesda Guidelines $(2,18)$.

Immunohistochemistry. To identify misexpression of the MMR gene, we performed immunohistochemistry staining in the colon cancer specimens of the proband. The hMSH2 protein was expressed normally, but the hMLH1 protein was not stained (Fig. 2).

Analysis of germline mutation. We performed direct DNA sequencing of exons of the $h M S H 2$ and $h M L H 1$ genes with peripheral blood of the proband. The base sequence of the MSH2 gene was normal. We found a heterozygote mutation in which a $\mathrm{C}$ was inserted at the 1780th base in the 16th exon of the $h M L H 1$ gene and a frameshift resulted due to the mutation (Fig. 3). Consequently, the sequence after the 587th amino acid was changed, and the 592th amino acid was estimated to change into a premature stop codon inducing a deletion of $21 \%$ of the $\mathrm{C}$ terminal portion of the hMLH1 protein (Fig. 3B). We performed the same experiment with other members of the family and found the same mutation in the same gene in 13 (III6, IV1-4, V2-9) of 20 (III3, III6, IV1-5, V1-13) family members. This mutation is new and has never been reported in the HNPCC database (http://www. insight-group.org; http://www.nfdht.nl).

Clinical examination. As a result of colonoscopy, V4 (31-yearold, female) had an adenocarcinoma in situ, and V7 (34-yearold, male) had an adenocarcinoma (stage IIIc, T2N2M0 at computed tomography; Fig. 4). There were no abnormal results from the Papanicolaou smear and TVUs performed on female family members.

Western blot analysis for the hMLH1 protein expression variation in normal colon tissue. The $\mathrm{N}$-terminal portion of the hMLH1 protein was detected in all of the family members. However, the $\mathrm{C}$ terminal portion of the hMLH1 protein was not detected in the tissues of V4 and V7, who were diagnosed with colon cancer. Carriers (V3, V5, V6), who had mutations of the $h M L H 1$ in spite of normal colonoscopic findings, had low densities of protein expression of the $\mathrm{C}$ terminal, approximately $25-50 \%$ lower density than that of normal expression with no mutations (IV5, V11, V12). The detection rate of the $\mathrm{N}$ terminal of the hMLH1 protein was similar in both groups. Therefore, the hMLH1 protein expression was 
A

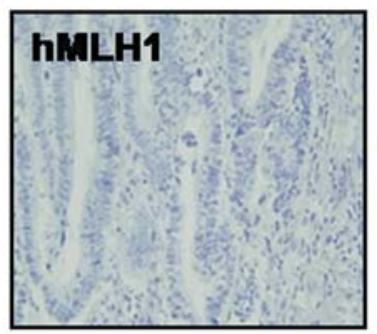

B

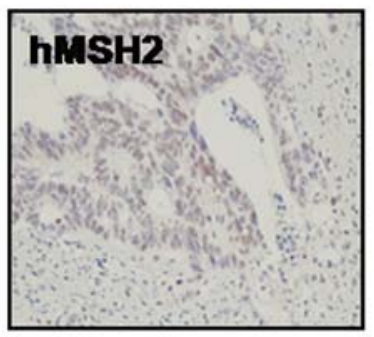

Figure 2. Immunohistochemical staining for hMLH1 and hMSH2 proteins in colorectal adenocarcinoma tissue of HNPCC patient. (A) The expression of hMLH1 protein in a colorectal adenocarcinoma. Nuclear staining of hMLH1 protein is not observed in tumor glands (x400). (B) Tumor glands show intense nuclear staining of hMSH2 protein $(\mathrm{x} 400)$.

affected in colon tissues of the family members with DNA mutations, especially V4 and V7 who were diagnosed with colon cancer, did not express the $\mathrm{C}$ terminal portion at all (Fig. 5).

\section{Discussion}

Although genetic testing is valuable for early diagnosis and management of HNPCC, it is time-consuming and expensive. Therefore, we need an appropriate sorting guideline for genetic testing. The individuals that fulfill the Amsterdam criteria II should undergo genetic testing. However, many cases that have shown a need for genetic testing do not fulfill this criteria, because the criteria is too strict. To guide decisions on whether families that do not fulfill the Amsterdam criteria II should undergo genetic testing, the Bethesda guidelines and the revised Bethesda guidelines were developed in 1996 and in $2002(2,18)$.
A

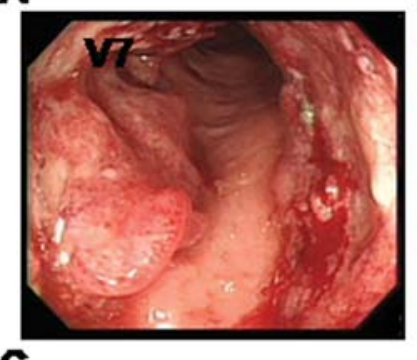

C.

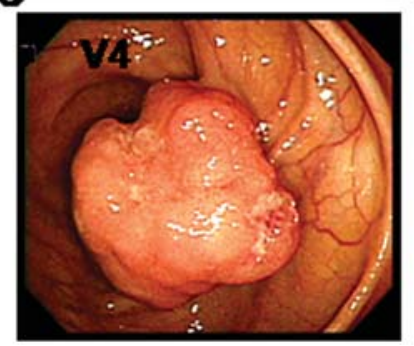

D
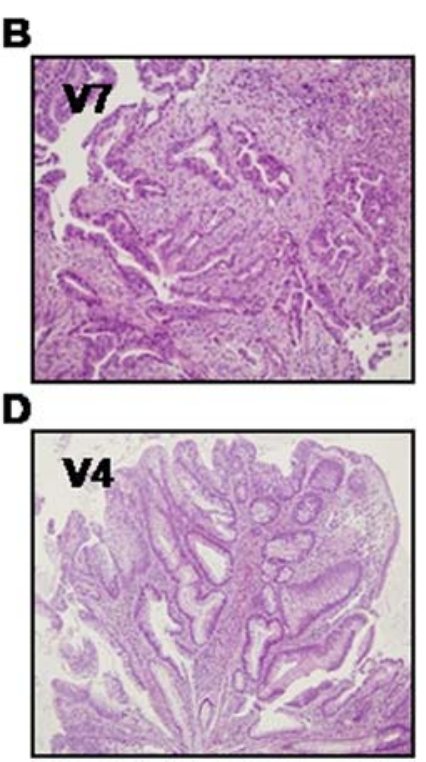

Figure 4. (A) Colonoscopic finding (V7). Large ulceroinfiltrating mass involving the bowel circumference was noted in the rectum. The lesion is friable and covered with dirty exudate. (B) Histologic feature of adenocarcinoma of the colon (V7). The tumor cells show moderately differentiated tubular glands with marked desmoplasia (H\&E, x200). (C) Colonoscopic finding (V4). It shows a $3-\mathrm{cm}$ sized polypoid mass with ulcerations in the cecum. (D) Histologic feature of tubular adenoma with low grade and focal high grade dysplasia of the colon (V4). Section shows atypical tubular epithelium with hyperchromatic nuclear stratification (H\&E, x100).

As shown in Fig. 1, this family does not fulfill the Amsterdam criteria II (17), but should undergo genetic testing according to the revised Bethesda guidelines (18). The revised Bethesda guidelines recommend starting the process of molecular diagnosis by testing for a tumor for

A

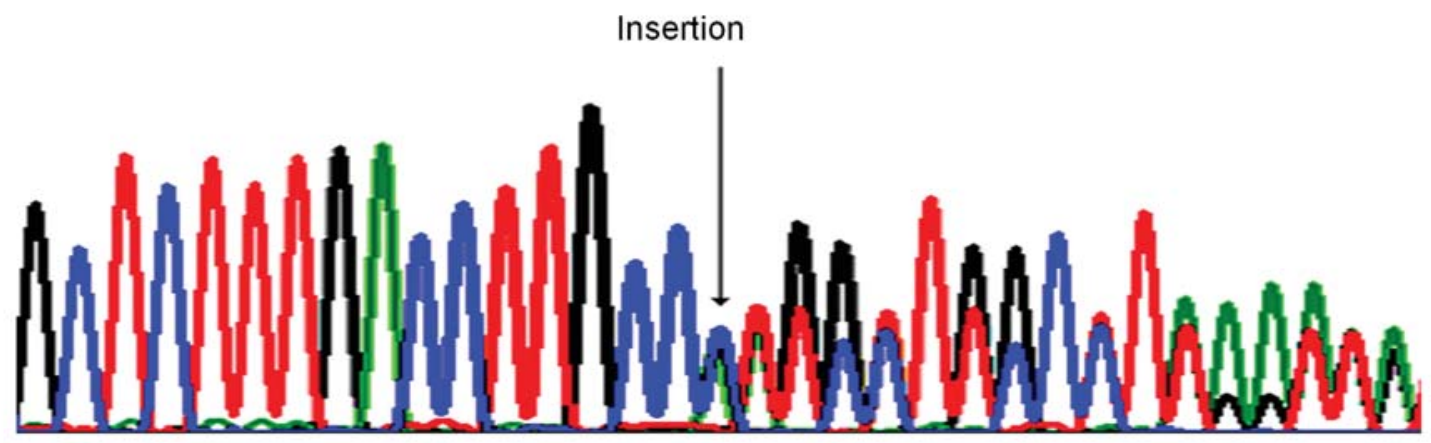

B

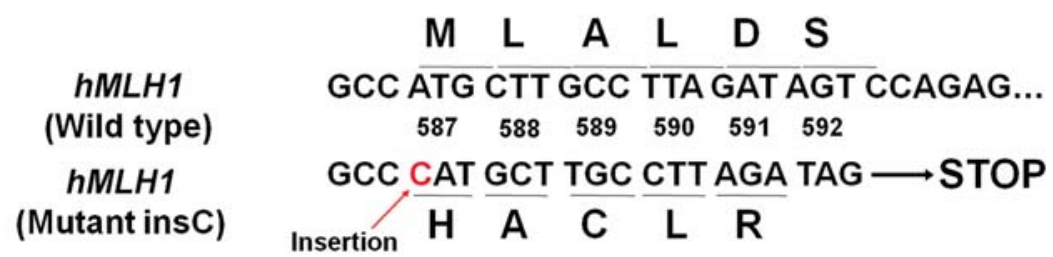

Figure 3. Direct sequencing of the mutant $h M L H 1$ gene and the effect of translation of $h M L H 1$ gene by mutation. (A) C insertion, followed by stop codon, occurred at the 16th exon in $h M L H 1$ gene of the proband. Arrow shows the mutation site of the C insertion. (B) Premature termination resulting from frameshift mutation by $\mathrm{C}$ insertion was elucidated. 


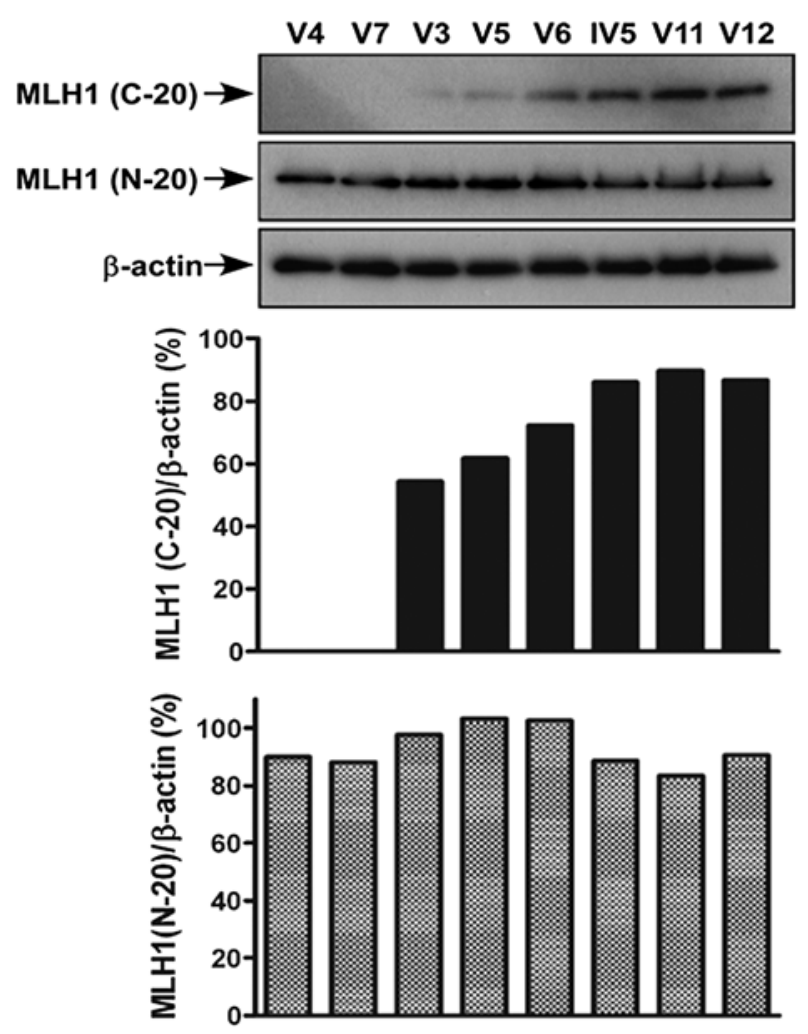

Figure 5. Western blot analysis of hMLH1 expression. Lanes 1-2, patients who have colon cancer (V4, V7); lanes 3-5, carriers who have germline mutation but no colon cancer (V3, V5 and V6); lanes 6-8, normal family members (IV5, V11 and V12). It revealed loss of C-terminal portion (C-20) of hMLH1 expression in colon tissue of $\mathrm{V} 4$ and $\mathrm{V} 7$, and the expression was decreased in V3, V5 and V6, by 54, 62, and 73\%, respectively. The germline mutation did not affect the expression level of $\mathrm{N}$-terminal portion (N-20) of hMLH1. ß-actin was measured as internal control.

MSI or protein expression of hMLH1 and hMSH2 by immunohistochemistry, followed by germline analysis of the suspected gene (19-21). The testing method for MSI based on polymerase chain reaction (PCR) (22) is not routinely performed due to it being expensive and time-consuming. Recently, some studies suggest that immunohistochemistry is effective in sensitivity, specificity, positive predictive value and negative predictive value. Thus immunohistochemistry has become powerful as a rapid and useful method for MSI (23-26). In this work, based on the guidelines of molecular biology, immunohistochemistry for hMLH1 and hMSH2 proteins were performed as the first step of molecular screening. As a result, we found expressional abnormality of MLH1 in the tumor tissue from the proband (Fig. 2). We carried out direct DNA sequencing of the $h M L H 1$ gene as the next step in molecular screening. Germline $h M L H 1$ mutation of a $\mathrm{C}$ insertion at the 1780th amino acid of exon 16, leading to a premature stop codon, was determined by direct sequencing of the PCR amplified exon. Because of this mutation, $21 \%$ deletion of the $\mathrm{C}$ terminal portion of the hMLH1 protein occurred (Fig. 3). As a result of performing the same examination to all of the family members, 13 out of 20 people had the same genetic mutation in the same region (Fig. 1). This mutation had not been previously reported in the HNPCC database (http://www.insight-group.org; http://www. nfdht.nl).
The most important purpose for visiting HNPCC patients and their family is to educate the high-risk family of cancer development, moreover, to detect cancer in the early stage and treat it by routine evaluation. Therefore, all of the HNPCC family members should have proper management from the age of 20-25 years to 50 years or more (21). A full colonoscopy every 1-3 years should be started at age 20-25 $(16,27)$ and every year after age 35 due to high risk of colorectal cancer $(21,28)$. Endometrial cancer is the most common extracolonic cancer and lifetime risk of ovarian cancer is also high in HNPCC (29-31). Thus, annual gynecologic surveillance, such as TVUs, pelvic examination, CA125 detection and Papanicolaou smear is recommended from age 30-35 (32).

We found the same germline MMR mutation in 13 individuals of this family (III6, IV1-4, V2-9) (Fig. 1). However, 8 family members did not start any genetic counseling or predictive testing except III6, IV1-4. We performed colonoscopies and gynecologic surveillance (only in females) to 8 family members and found new colorectal cancer which had no clinical symptoms in 2 family members (Fig. 4; V4 and V7). Surprisingly, their ages were 31 and 34 years, which were much earlier than the mean age, 44 years, of diagnosis in HNPCC $(21,33)$. Especially, although V7 was young, the stage of cancer was IIIc (T2N2M0) at computed tomography. To investigate how the mutated MMR gene of this family affects actual tissue, normal colon tissue was examined by Western blot analysis. A different pattern was found in the hMLH1 mutant protein (Fig. 5). Family members who had the genetic DNA mutation were affected by the expression of a defective hMLH1 protein in the actual colon tissue. Hence, we could tell there was a functional problem. However, there was a difference in hMLH1 expression between the group diagnosed as colon cancer (V4 and V7) and the carrier group who did not have clinical symptoms (V3, 5 and 6). These non-penetrant carriers could manifest the tumor someday. Therefore, careful follow-up is needed. This phenomenon might be explained by the level of inactivation. MMR genes responsible for HNPCC can develop cancer when two alleles are inactivated together. One of the alleles is inactivated at the level of germline cells, and the other is inactivated at the level of somatic cells. As an HNPCC patient is the carrier of an inactivated allele at the germline level at birth, cells of the carrier can develop normally because of the sufficient compensation by the wild-type allele. However, when a small benign tumor is created by a mutation of the APC gene (34), one of the cell development control genes, the wild-type allele of MMR located in the somatic cell is inactivated by abnormal methylation (35). After both alleles of MMR are inactivated, genetic instability causes accelerating multiple genetic mutations of K-ras, p53, and DCC, and they are accumulated resulting in cancer $(7,36,37)$. Therefore, V4 and V7 who have colon cancer may experience this process and two of their alleles are thought to be inactivated, while $\mathrm{V} 3, \mathrm{~V} 5$ and V6 are underway in this process.

With these facts given, this family fulfills the Amsterdam criteria II, and we consider that HNPCC occurred by a new hMLH1 mutation. This new hMLH1 mutation is pathogenic as evidenced below. First, the cancer occurs only in the family members who have this mutation. Second, there is a considerable defect of $21 \%$ in C-terminal portion of hMLH1 
protein missing due to this mutation. Third, the defective hMLH1 protein showed abnormal findings in colon tissue. Further study requires obtaining objective verification of pathogenicity.

Through this study, we detected a novel $h M L H 1$ mutation that was not reported before. Also, we experienced the gravity of the early management of the family who do not fulfill the Amsterdam criteria II, but need genetic study. Furthermore, this study may help diagnose and genetically manage the HNPCC family.

\section{Acknowledgments}

The authors thank Yoon-Jin Kwak for technical support.

\section{References}

1. Lynch HT and de la Chapelle A: Genetic susceptibility to nonpolyposis colorectal cancer. J Med Genet 36: 801-818, 1999.

2. Rodriguez-Bigas MA, Boland CR, Hamilton SR, et al: A National Cancer Institute Workshop on hereditary non-polyposis colorectal cancer syndrome: meeting highlights and Bethesda guidelines. J Natl Cancer Inst 89: 1758-1762, 1997.

3. Banno K, Susumu N, Hirao T, et al: Identification of germline $\mathrm{MSH} 2$ gene mutations in endometrial cancer not fulfilling the new clinical criteria for hereditary non-polyposis colorectal cancer. Cancer Genet Cytogenet 146: 58-65, 2003.

4. Fishel R, Lescoe MK, Rao MR, et al: The human mutator gene homolog $\mathrm{MSH} 2$ and its association with hereditary non-polyposis colon cancer. Cell 75: 1027-1038, 1993.

5. Leach FS, Nicolaides NC, Papadopoulos N, et al: Mutations of a $m u t S$ homolog in hereditary non-polyposis colorectal cancer. Cell 75: 1215-1225, 1993.

6. Bronner CE, Baker SM, Morrison PT, et al: Mutation in the DNA mismatch repair gene homologue $h M L H 1$ is associated with hereditary non-polyposis colon cancer. Nature 368: 258-261, 1994.

7. Papadopoulos N, Nicolaides NC, Wei YF, et al: Mutation of a mutL homolog in hereditary colon cancer. Science 263: 1625-1629, 1994.

8. Akiyama Y, Sato H, Yamada T, Nagasaki H, Tsuchiya A, Abe R and Yuasa Y: Germ-line mutation of the $h M S H 6 / G T B P$ gene in an atypical hereditary non-polyposis colorectal cancer kindred. Cancer Res 57: 3920-3933, 1997.

9. Miyaki M, Konishi M, Tanaka K, et al: Germline mutation of MSH6 as the cause of hereditary non-polyposis colorectal cancer. Nat Genet 17: 271-272, 1997.

10. Nicolaides NC, Papadopoulos N, Liu B, et al: Mutations of two PMS homologues in hereditary non-polyposis colon cancer. Nature 371: 75-80, 1994.

11. Peltomäki P and Vasen $\mathrm{H}$ : Mutations associated with HNPCC predisposition - update of ICG-HNPCC/INSiGHT mutation database. Dis Markers 20: 269-276, 2004.

12. Wahlberg S, Liu T, Lindblom P and Lindblom A: Various mutation screening techniques in the DNA mismatch repair genes $h M S H 2$ and $h M L H 1$. Genet Test 3: 259-264, 1999.

13. Syngal S, Fox EA, Eng C, Kolodner RD and Garber JE: Sensitivity and specificity of clinical criteria for hereditary nonpolyposis colorectal cancer associated mutations in $\mathrm{MSH} 2$ and MLH1. J Med Genet 37: 641-645, 2000.

14. Wijnen JT, Vasen HF, Khan PM, et al: Clinical findings with implications for genetic testing in families with clustering of colorectal cancer. N Engl J Med 339: 511-518, 1998.

15. Farrington SM, Lin-Goerke J, Ling J, Wang Y, Burczak JD, Robbins DJ and Dunlop MG: Systematic analysis of $h M S H 2$ and $h M L H 1$ in young colon cancer patients and controls. Am J Hum Genet 63: 749-759, 1998.

16. Vasen HFA, Merklin JP, Khan PM and Lynch HT: The International Collaborative Group on hereditary non-polyposis colorectal cancer (ICG-HNPCC). Dis Colon Rectum 34: 424-425, 1991.
17. Vasen HFA, Watson P, Merklin JP and Lynch HT: New clinical criteria for hereditary non-polyposis colorectal cancer (HNPCC, Lynch syndrome) proposed by the International Collaborative Group HNPCC. Gastroenterology 116: 1453-1456, 1999.

18. Umar A, Boland CR, Jonathan P, et al: Revised Bethesda guidlines for hereditary non-polyposis colorectal cancer (Lynch syndrome) and microsatellite instability. J Natl Cancer Inst 96: 261-268, 2004.

19. Pinol V, Castells A, Andreu M, et al: Accuracy of revised Bethesda guidlines, microsatellite instability, and immunohistochemistry for the identification of patients with hereditary non-polyposis colorectal cancer. JAMA 293: 1986-1994, 2005.

20. Lindor NM, Burgart LJ, Leontovich O, et al: Immunohistochemistry versus microsatellite instability testing in phenotyping colorectal tumors. J Clin Oncol 20: 1043-1048, 2002.

21. Abdel-Rahman WM, Mecklin JP and Peltomaki P: The genetics of HNPCC: application to diagnosis and screening. Crit Rev Oncol Hematol 58: 208-220, 2006.

22. Boland CR, Thibodeau SN, Hamilton SR et al: A national cancer institute workshop on microsatellite instability for cancer detection and familial predisposition: development of international criteria for the determination of microsatellite instability in colorectal cancer. Cancer Res 58: 5248-5257, 1998.

23. Ward R, Meagher A, Tomlinson I, O'Connor T, Norrie M, Wu R and Hawkins N: Microsatellite instability and the clinicopathological features of sporadic colorectal cancer. Gut 48: 821-829, 2001.

24. Cawkwell L, Gray H and Murgatroyd H: Choice of management strategy for colorectal based on a diagnostic immunohistochemical test for detective mismatch repair. Gut 45: 409-415, 1999.

25. Thibodeau SN, French AJ, Roche PC, et al: Altered expression of $h M S H 2$ and $h M L H 1$ in tumors with microsatellite instability and genetic alterations in mismatch repair genes. Cancer Res 56: 4836-4840, 1996

26. Terdiman JP, Gum JR, Conrad PG, et al: Efficient detection of hereditary non-polyposis colorectal cancer gene carriers by screening for tumor microsatellite instability before germline genetic testing. Gastroenterology 120: 21-30, 2001.

27. Burke W, Petersen G, Lynch P, et al: Recommendations for follow-up care of individuals with an inherited predisposition to cancer. I. hereditary non-polyposis colorectal cancer. JAMA 277: 915-919, 1997.

28. Park JG and Kim IJ: Hereditary colorectal cancer. Korean J Gastroenterol 45: 78-87, 2005.

29. Aarnio M, Merklin JP, Aaltonen LA, Nystrom-Lahti M and Jarvinen HJ: Life-time risk of different cancers in hereditary non-polyposis colorectal cancer (HNPCC) syndrome. Int J Cancer 64: 430-433, 1995

30. Hendriks YMC, Wagner A, Morreau H, et al: Cancer risk in hereditary non-polyposis colorectal cancer due to MSH6 mutation: impact on counseling and surveillance. Gastroenterology 127: 17-25, 2004.

31. Brown GJ, St John DJ, Mavrae FA and Aittomaki K: Cancer risk in young women at risk of hereditary non-polyposis colorectal cancer: implications for gynecologic surveillance. Gynecol Oncol 80: 346-349, 2001.

32. Rijcken FEM, Mourits MJE, Kleibeuker JH, Hollema H and van der Zee AGJ: Gynecologic screening in hereditary nonpolyposis colorectal cancer. Gynecol Oncol 91: 74-80, 2003.

33. Jass JR, Smyrk TC, Stewart SM, Lane MR, Lanspa SJ and Lynch HT: Pathology of hereditary non-polyposis colorectal cancer. Anticancer Res 14: 1631-1634, 1994.

34. Powell SM, Zilz N, Beazer-Barclay Y, et al: APC mutations occur early during colorectal tumorigenesis. Nature 359: 235-237, 1992.

35. Baylin SB, Makos M, Wu JJ, Yen RW, de Bustros A, Vertino P and Nelkin BD: Abnormal patterns of DNA methylation in human neoplasia: potential for tumor progression. Cancer Cells 3: 383-389, 1991

36. Wood RD, Mitchell M, Sgouros J and Lindahl T: Human DNA repair genes. Science 291: 1284-1289, 2001.

37. Knudson A, Hethcote $\mathrm{H}$ and Brown B: Mutation and childhood cancer: a probablistic model for the incidence of retinoblastoma. Proc Natl Acad Sci USA 72: 5116-5124, 1975. 